\title{
Problem niewypłacalności jednostek samorządu terytorialnego
}

\section{The Problem of Local Authority Insolvency}

Streszczenie. W niniejszym opracowaniu podjęto problematykę niewypłacalności jednostek samorządu terytorialnego oraz różnorodnych metod zaradczych służących sanacji ich gospodarki finansowej. Pierwsza część pracy poświęcona została przybliżeniu znaczenia i istoty zjawiska niewypłacalności występującego we wspólnotach samorządowych. Kolejna - syntetycznej typologii oraz zwięzłej charakterystyce poszczególnych metod zaradczych znajdujących współcześnie zastosowanie. Całość prezentowanych rozważań osadzona jest na charakterystyce i ocenie normatywnej konstrukcji metody zaradczej obowiązującej w Polsce. Natomiast ostatnia część podsumowuje analizowane tematy.

Słowa kluczowe: niewypłacalność; metody zaradcze; postępowanie naprawcze.

Abstract. In this article, there has been undertaken the specific problem of local authority insolvency, and a diverse anti-bankruptcy methods which enforce

Na podstawie pracy magisterskiej pt. Wpływ długu publicznego na sytuację finansowq jednostek samorzqdu terytorialnego, promotor - prof. zw. dr hab. Jerzy Małecki (Uniwersytet im. Adama Mickiewicza w Poznaniu, Wydział Prawa i Administracji). 
against the insolvency. The first section describes the particular role of local authority insolvency, as well as the essence of this phenomenon in modern countries. Another part of the work revives different types of anti-bankruptcy methods. However, the last section summarizes the analyzed topics.

Keywords: insolvency; anti-bankruptcy methods; reorganization proceedings.

\section{Wprowadzenie}

Zainteresowanie problematyką niewypłacalności jednostek samorządu terytorialnego (dalej: j.s.t.) ze strony przedstawicieli nauki i praktyki podlega zazwyczaj niezwykle silnej intensyfikacji w okresach załamania się cyklu koniunkturalnego, będącego zwiastunem ogólnego zastoju, oraz braku oczekiwanej dynamiki wzrostu potencjału ekonomicznego państwa. Taka sytuacja parokrotnie dała się już zaobserwować, uwidaczniając się w szczególny sposób podczas: zapaści finansów samorządowych w okresie międzywojennym, na początku XXI w., oraz - co znamienne - obecnie. Z jednej strony można to potraktować jako chwilowy, acz „zdrowy” przejaw troski tych wszystkich, którym „leży na sercu” dobre (tzn. gospodarne) zarządzanie finansami wspólnot samorządowych. Dokonanie bowiem ad hoc rzetelnej i sumiennej analizy obecnego ustawodawstwa w trakcie ${ }^{1}$ - niekiedy również ex post - następowania rozmaitych kryzysowych zjawisk w obrębie finansów komunalnych, nie tylko pozwala na wyrobienie sobie określonego zdania na odnośny temat, ale przede wszystkim umożliwia skonfrontowanie przyjętych w tym zakresie teoretycznych konstrukcji normatywnych z praktyką życia gospodarczego, której następstwa nie zawsze będą licować z zinstytucjonalizowanymi rozwiązaniami przyjętymi przez kontrfaktycznego racjonalnego prawodawcę $^{2}$. Z drugiej zaś strony zarysowane powyżej epizodyczne podejście do problemu niewypłacalności j.s.t. w momencie, gdy zbliża się okres zapaści gospodarczej, może wskazywać na to, że naukowcy i lokalni wło-

1 Zgodnie z postulatem realistycznej koncepcji prawa law in action, nakazującej badanie prawa w działaniu - S. Wronkowska, Z. Ziembiński, Zarys teorii prawa, Poznań 1997, s. 67.

2 M. Zieliński, Wykładnia prawa. Zasady, reguły, wskazówki, Warszawa 2010, s. 294-297. 
darze zaczynają interesować się rzeczoną problematyką dopiero wtedy, gdy groźba niewypłacalności j.s.t. jest już realna. Taki stan rzeczy nie powinien być w dalszym ciągu utrzymywany. Dowodzi bowiem pewnej beztroski tkwiącej w rozumowaniu, iż okres prosperity będzie trwać nieprzerwanie, w związku z czym nie warto pochylać się nad kwestią niewypłacalności, która najpewniej i tak nie nastąpi. W ten sposób traci się z pola widzenia pewną oczywistość - ba, zaciera się na tyle ostrość percepcji, że wszelkie tego następstwa niedostrzeżone uprzednio mogą być przykre. Nie wnikając głębiej w przyczyny i skutki tej krótkowzroczności, warto zaakcentować potrzebę stałego mierzenia się z tym problemem przez zarówno bieżącą analizę wyprowadzanych w tym zakresie rozwiązań regulacyjnych, jak i czerpanie z doświadczeń już uzyskanych w konfrontacji z nadmiernym zadłużeniem.

Celem niniejszego opracowania jest przybliżenie zjawiska niewypłacalności j.s.t. oraz ukazanie różnorodnych metod zaradczych służących sanacji ich gospodarki finansowej w obliczu „plajty”. Autor szczególnie dużo miejsca poświęcił rozwiązaniom regulacyjnym, które znajdują zastosowanie w wybranych systemach finansowych rozwiniętych państw, osadzając całość prezentowanych rozważań na charakterystyce i ocenie normatywnej konstrukcji metody zaradczej obowiązującej w Polsce.

\section{Istota niewypłacalności jednostek samorządu terytorialnego}

Do pojęcia niewypłacalności można podchodzić z różnych perspektyw. Można w sposób zarówno negatywny, jak i pozytywny objaśnić jego sens, niemniej w wartkim nurcie rozważań nad istotą tego zjawiska utarła się praktyka uprzedniego objaśniania terminu wypłacalności, którego zrozumienie pozwala dopiero wyrobić sobie określony pogląd na stan przeciwstawny. W kontekst tej problematyki wpisuje się sformułowana przez M. Bitnera definicja wypłacalności, przez którą autor ten rozumie wynikającą z dobrej sytuacji finansowej j.s.t. możliwość terminowego wywiązywania się ze wszystkich zobowiązań pieniężnych, będących w szczególności efektem zaciągniętych kredytów i pożyczek oraz wyemitowanych 
walorów dłużnych, przy zaspokojeniu bieżących potrzeb wspólnoty samorządowej oraz zrealizowaniu planowanych wydatków inwestycyjnych ${ }^{3}$.

Z kolei pośród autorów zagranicznych w interesujący sposób do pojęcia wypłacalności podchodzi S.M. Groves ${ }^{4}$, rozróżniając:

1. wypłacalność w krótkim okresie (ang. short run solvency), która oznacza zdolność generowania przez władzę lokalną takiej ilości środków finansowych, która pozwoli jej na pełne pokrycie zaciągniętych uprzednio krótkoterminowych zobowiązań - nieprzekraczających roku budżetowego;

2. wypłacalność $w$ długim okresie (ang. long run solvency), która oznacza zdolność do pokrywania przez daną jednostkę samorządową kilkuletnich wydatków, które mogą znajdować swe umocowanie w wieloletniej prognozie finansowej.

Natomiast według J. Blacka wypłacalność należy pojmować jako możność dysponowania majątkiem o wartości przewyższającej zobowiązania pieniężne danej jednostki samorządowej ${ }^{5}$. Autor dodaje przy tym, iż w sytuacji, gdy majątkiem jest gotówka bądź walory dłużne, wypłacalność tej jednostki jest oczywista. Jeżeli jednak wspomniany podmiot posiada majątek, na który nie ma popytu na rynku, to jego wypłacalność pozostaje w dużej mierze kwestią indywidualnej oceny.

Rozważając przywołane ut supra ujęcia wypłacalności, można dojść do przekonania, iż terminem doń pokrewnym jest płynność finansowa ${ }^{6}$, która oznacza zdolność jednostki samorządowej do wywiązywania się z zaciągniętych uprzednio krótkoterminowych zobowiązań pieniężnych ${ }^{7}$. Nie jest przy tym istotne - w ślad za powyższym rozumieniem tego pojęcia - źródło, z jakiego j.s.t. będzie czerpać niezbędne zasoby do pokrywania narastających zobowiązań. Tak więc pojmowana płynność finansowa będzie

3 M. Bitner, Gmina na rynku kapitałowym. Podstawy zarzqdzania długiem komunalnym, Warszawa 1999, s. 31.

4 S.M. Groves, An Introduction to Evaluating Financial Condition, [w:] J. Matzer, Practical Financial Management. New Techniques for Local Government, Washington 1984, s. 14.

J. Black, Słownik ekonomii, Warszawa 2008, s. 546.

E. Stolorz-Krzisz, Niewypłacalność gminy, „Wspólnota”1998, nr 18, s. 11.

B. Gruszka, Ryzyko płynności finansowej, [w:] L. Jaworski (red.), Współczesny bank, Warszawa 2001, s. 343. 
występować wówczas, gdy saldo wzajemnych przepływów finansowych w określonym przedziale czasowym nie będzie odnotowywało ujemnych wyników. Rzadko jednak w praktyce dochodzi do takiej sytuacji, w której przeważająca większość jednostek samorządowych jest w stanie terminowo regulować obciążające je spłaty z tytułu zaciągniętych długów. Częstokroć nadmiar nakładanych na nie obowiązków publicznych, przy jednoczesnym dość ograniczonym wachlarzu źródeł dochodów własnych, prowadzi nieuchronnie do występowania przejściowych napięć i trudności z bieżącym utrzymaniem płynności finansowej. Skutkiem zaś długotrwałego utrzymywania się takiego stanu rzeczy w budżetach j.s.t. jest popadnięcie przez nie w stan permanentnej niewypłacalności. Naturalnie rodzi się w tym miejscu pytanie, czy jednostki te będą wówczas mogły zbankrutować, czy też nie? Innymi słowy, czy będą mogły zostać poddane takiej jak inni uczestnicy obrotu prawnego zwyczajnej procedurze upadłościowej ze wszelkimi tego konsekwencjami? Prima facie zdawać by się mogło, iż jednostka samorządowa, jako wyodrębniona od państwa strukturalnie i podmiotowo osoba prawa publicznego, już od momentu jej ukonstytuowania jest wyposażona w zdolność upadłościową, będącą jednym z aspektów zdolności prawnej pojmowanej jako atrybucja określonej kategorii jednostek do uzyskiwania praw cywilnych, zaciągania i umarzania zobowiązań we własnym imieniu i na swoją rzecz ${ }^{8}$. Pogląd ten tym bardziej może wydawać się słuszny, że przecież sam fakt bycia nosicielem zdolności upadłościowej nierozerwalnie wiąże się z kwestią ponoszenia przez dany podmiot odpowiedzialności za zaciągnięte zobowiązania. A jak wiadomo, j.s.t. stanowią niezwykle kapitałochłonną grupę dłużników, zawierającą rokrocznie najrozmaitszego rodzaju zobowiązania. Stąd też - podążając w ślad za powyższym tokiem rozumowania - brak takiej zdolności niezawodnie wyłączałby wierzycieli od możliwości skutecznego przejęcia kontroli nad majątkiem dłużnika (j.s.t.) w celu wyegzekwowania od nich swoich należności ${ }^{9}$. Niemniej na przekór temu zapatrywaniu stoi specyficzna pozycja samorządu terytorialnego jako dłużnika publicznego, co przejawia się m.in. w konieczności spełniania

8 M. Przychodzki, K. Sąciński, Brak zdolności upadłościowej osób prawa publicznego, „Przegląd Prawa Handlowego” 2006, nr 4, s. 27.

9 Tamże. 
podstawowych funkcji, do jakich został powołany, mimo przejściowych problemów z utrzymaniem płynności ${ }^{10}$. Jakiekolwiek bowiem poważniejsze zachwianie bądź zapaść gospodarki komunalnej w sytuacji dopuszczenia do nieopanowanego bankructwa poszczególnych jednostek samorządowych groziłyby w praktyce możliwością ich przejęcia bądź całkowitej likwidacji - co z oczywistych względów nie powinno nigdy nastąpić. Stąd też, jako argument przemawiający za brakiem możności ogłoszenia bankructwa j.s.t. podnosi się także - celem wzmocnienia powyższej argumentacji - że szczególny charakter świadczonych przez nie zadań wymaga zapewnienia wspólnotom samorządowym niezachwianej gwarancji stałego i nieprzerwanego działania w obrębie sfery użyteczności publicznej ${ }^{11}$. Jest to słuszne rozwiązanie, albowiem j.s.t. są nie tylko w pełni finansowane ze środków publicznych i wobec tego jakakolwiek konfiskata ich mienia w istocie narażałaby res publico usui destinatae na nieracjonalne uszczuplenie, ale też co istotniejsze - mogłaby pozbawić mieszkańców wspólnoty samorządowej wielu konstytucyjnie nabytych uprawnień. Jak zauważa A. Kopańska, samorządy terytorialne, zresztą podobnie jak państwa, działają niezależnie od ich kondycji finansowej, a ewentualna niewypłacalność tych podmiotów nie może prowadzić do ich likwidacji ${ }^{12}$. Nie jest więc możliwe skreślenie z mapy jednostki samorządu terytorialnego ze względu na jej szczególny status podmiotu publicznego, który przecież został powołany po to, aby zaspokajać rzeczywiste potrzeby lokalnej wspólnoty ${ }^{13}$. Dla rozwiania już wszelkich wątpliwości dotyczących analizowanej kwestii, warto tylko wspomnieć, że w sukurs drugiemu z zaprezentowanych stanowisk idzie polski ustawodawca, stwierdzając kategorycznie, iż nie można ogłosić upadłości j.s.t. ${ }^{14}$, co wydaje się ze wszech miar słuszne.

10 A. Kopańska, Zewnętrzne źródła finansowania inwestycji jednostek samorzq̨du terytorialnego, Warszawa 2003, s. 78.

11 M. Przychodzki, K. Sąciński, Brak zdolności upadłościowej.., s. 27; R. Szarek, Upadłość komunalnych jednostek organizacyjnych, Wspólnota 1998, nr 31, s. 24.

A. Kopańska, Zewnętrzne źródła finansowania..., s. 78-79.

J. Zimmermann, Prawo administracyjne, Kraków 2005, s. 130.

14 Art. 6 pkt 2 ustawy z dnia 28 lutego 2003 r. Prawo upadłościowe i naprawcze (Dz.U. Nr 175, poz. 1361 ze zm.). 


\section{Metody zaradcze stosowane przez państwo wobec niewypłacalności jednostek samorządu terytorialnego}

\subsection{Rodzaje poszczególnych metod zaradczych}

Doświadczenie innych aniżeli Polska krajów wskazuje, iż w sytuacji, gdy samorząd doznaje przewlekłego stanu niewypłacalności, za akceptowalne rozwiązania mogące przysłużyć się sanacji jego gospodarki finansowej, uznaje się trzy alternatywne metody reagowania państwa ${ }^{15}$ :

1. Bezpośrednie zaangażowanie państwa w przywrócenie danej jednostce samorządowej pewnego stopnia stabilności finansowej, które opiera się na wyasygnowaniu określonej transzy środków finansowych jednostce samorządu terytorialnego odznaczającej się brakiem wypłacalności. W istocie ta metoda będzie się przejawiać bezpośrednim, tzn. pozbawionym ogniw pośrednich, dostarczeniem przez państwo niewypłacalnej jednostce takiej ilości środków, by pozwoliły one w oznaczonym czasie spłacić jej wymagalne zobowiązania. W zależności od przyjętego modelu finansowania działań naprawczych wyróżnia się następujące jej formy:

a. dotacja z budżetu państwa;

b. pożyczka z budżetu państwa;

c. ściśle oznaczona pula środków z budżetu państwa, która jest przewidziana w ramach tzw. mechanizmów wyrównawczych;

d. ściśle oznaczona pula środków ze specjalnie utworzonego na ten cel funduszu samorządowego.

2. Pośrednie zaangażowanie państwa w przywrócenie danej jednostce samorządowej pewnego stopnia stabilności finansowej opiera się na pozafinansowych działaniach ze strony władzy publicznej, sprowadzających się w ostatecznym rozrachunku do przedsiębrania takich środków zaradczych, które nie wymagają od niej ponoszenia finan-

15 Zob. T. Duve, W. Drechsler, Insolvent Local Government: Lesson from Germany, s. 7-9, www.nispa.org/files/conferences/2010/papers/201004121221300.Duve_Drechsler.pdf, (dostęp: 30.09.2014 r.); M. Wiewióra, Środki zaradcze państwa wobec niewypłacalności jednostki samorzqdu terytorialnego, „Samorząd Terytorialny” 2009, nr 12, s. 35. 
sowych kosztów wychodzenia przez jednostki samorządowe ze stanu niewypłacalności. W istocie zatem cały ekonomiczny ciężar związany z wygenerowanym długiem będzie spoczywać na tej jednostce samorządowej, która popadła w stan zadłużenia, aczkolwiek w ściśle oznaczonych sprawach taka jednostka będzie mogła liczyć na ingerencję ze strony państwa w celu przezwyciężania dotykających ją problemów. Wyróżnia się następujące środki zaradcze, które może zaoferować państwo niewypłacalnej jednostce samorządowej w ramach tej metody:

a. powołanie lokalnego gremium (np. rady stanowej) nadzorującego sprawy finansowe j.s.t. dotkniętej kryzysem;

b. ułatwienie dostępu do rynków kapitałowych poprzez udzielanie poręczeń i gwarancji danej j.s.t., która chce uzyskać dostęp do nowych kredytów w celu spłaty dotychczasowego zadłużenia.

3. Brak zaangażowania państwa w ustabilizowanie kondycji finansowej danej j.s.t. dotkniętej nieoczekiwaną zapaścią polega na niereagowaniu przez państwo na jakiekolwiek symptomy niewypłacalności jednostek samorządowych. Tego rodzaju rozwiązanie wynika z akceptacji przez władzę państwową pewnej koncepcji, która, znajdując swe odzwierciedlenie w obowiązującym ustawodawstwie, w istocie oddala angażowanie się państwa w kwestię bankructwa wspólnot samorządowych. Według tego założenia zapewnia się j.s.t. niezwykle szeroką autonomię i niezależność przy prowadzeniu przez nie własnej działalności. Samodzielność ta - w powyższym rozumieniu - pojmowana jest jednak nie tylko jako ogół praw, z których można bez skrępowania korzystać, ale przede wszystkim jako szereg obowiązków, z których w przyszłości trzeba będzie się wywiązać ${ }^{16}$. Podczas gdy powszechnie się zakłada, że państwo ma obowiązek „coś zrobić” w razie, gdy j.s.t. doświadczy poważnych trudności finansowych, to - mając na względzie powyższą argumentację - założenie takie nie jest już rzeczą tak oczywistą. Przyjmując bowiem, że państwo nie

16 Avoiding local government financial crisis: the role of state oversight, Report No. 329 Citizens Research Council of Michigan 2000, s. 11, www.crcmich.org/PUBLICAT/ 2000s/2000/rpt329.pdf, (dostęp: 30.09.2014 r.). 
przyczyniło się do niewypłacalności jednostki samorządowej, można uznać za uzasadnioną argumentację, iż nie powinno być ono bezpośrednio zaangażowane $\mathrm{w}$ rozwiązywanie problemów finansowych poszczególnych jednostek samorządowych ${ }^{17}$. Pośród środków zaradczych, które znajdują zastosowanie w zaprezentowanej powyżej metodzie, należy wyszczególnić:

a. ustanowienie postępowania upadłościowego j.s.t.;

b. samoopodatkowanie j.s.t.;

c. likwidacja j.s.t. w celu konsolidacji.

\subsection{Zarys poszczególnych metod zaradczych z uwzględnieniem stopnia ich skuteczności}

W przypadku posłużenia się przez państwo metodą bezpośredniej pomocy finansowej nadmiernie zadłużonym j.s.t., koszty „wyjścia” z niewypłacalności owych jednostek samorządowych będzie ponosić cały kraj, a nie lokalna wspólnota samorządowa. Stąd też celowość udzielania przez państwo pomocy finansowej j.s.t., które znalazły się w sytuacji braku wypłacalności w następstwie własnych decyzji i działań, może rodzić jednak dość istotne wątpliwości ${ }^{18}$. W sytuacji bowiem nazbyt pochopnego kierowania publicznych środków pomocowych do jednostek samorządowych, które w ewidentny sposób przyczyniły się do złego stanu swych finansów, może dojść do umocnienia ich w przeświadczeniu o stałej gotowości państwa do spieszenia im z pomocą, nawet wówczas, gdy nie stoją za tym żadne rozsądne przesłanki. Władze takich jednostek w istocie doskonale zdają sobie sprawę z niegospodarności swoich poczynań. Toteż w obliczu uzyskania pewności, że w razie, gdy popadną w trudności, państwo je wesprze finansowo, tym bardziej nie okażą się skłonne do tego, aby szukać oszczędności ${ }^{19}$. Dlatego za niczym nieuzasadnione należy uznać kierowanie do tych jednostek jakichkolwiek środków publicznych, które nie

\footnotetext{
M. Wiewióra, Środki zaradcze państwa wobec niewypłacalności..., s. 40. Tamże, s. 46.

P. Swianiewicz, Finanse samorzqdowe, koncepcje, realizacja, podatki lokalne, Warszawa 2011, s. 191.
} 
tylko im się nie przysłużą, ale wręcz przeciwnie - mogą zaszkodzić, skłaniając takie jednostki do jeszcze bardziej wyrafinowanej postawy w zakresie rozrzutnego szafowania groszem publicznym ${ }^{20}$.

Przechodząc natomiast do instytucji gremiów lokalnych, warto podkreślić, iż oferują one niezwykle korzystną opcję rozwiązywania kryzysu finansowego objawiającego się niewypłacalnością z perspektywy państwa - przypisując odpowiedzialność za kryzys poszczególnym jednostkom samorządowym ${ }^{21}$. Państwo za pomocą ukonstytuowanego ciała rozpoczyna proces naprawy finansów komunalnych tak, aby wspomóc jednostkę lokalną, przy jednoczesnym zapewnieniu tymczasowego finansowania danej jednostki lub ułatwiając jej swobodny powrót na rynek kapitałowy.

Z kolei metoda zaradcza, polegająca na unormowaniu kwestii upadłości samorządu terytorialnego w ramach krajowych procedur, obciąża ciężarem kryzysu finansowego wierzycieli (podmioty udzielające kredytów). Rozwiązania te przewidują proces restrukturyzacji długu, który jest dogodny dla władz samorządowych, gdyż pozwala władzy samorządowej na przesunięcie odpowiedzialności za część swego długu na wierzycieli ${ }^{22}$, którzy nie mają wtenczas zapewnionej pełnej egzekwowalności dochodzonych roszczeń. Co prawda, wysokość tak dochodzonych należności może podlegać pewnej redukcji, niemniej wskutek właściwie przeprowadzonego postępowania upadłościowego j.s.t. wierzyciele będą mogli liczyć na zaspokojenie swoich roszczeń w możliwie maksymalnym stopniu. W sytuacji zaś zaistnienia w tym obszarze luki regulacyjnej mogłoby dojść do niczym niekontrolowanego przebiegu procesów związanych z niewypłacalnością poszczególnych jednostek samorządowych, przynosząc w następstwie tego znaczące straty nie tylko wierzycielom tych jednostek, ale również ich mieszkańcom, a także samemu Skarbowi Państwa ${ }^{23}$.

20 Por. W. Gonet, Program naprawczy jednostek samorzqdu terytorialnego w sytuacji utraty zdolności wykonania zobowiqzań, „Finanse Komunalne” 2008, nr 3, s. 17.

M. Wiewióra, Środki zaradcze państwa wobec niewypłacalności..., s. 46. Tamże.

23 A. Babczuk, Dług samorzq̨dowy w Polsce - propozycje de lege ferenda, [w:] L. Patrzałek (red.), Finansowanie jednostek samorzqdu terytorialnego w Polsce, Poznań-Wrocław 2004, s. 141. 
Stąd też wielu autorów uważa tę metodę za jedną z najbardziej optymalnych dla zachowania stabilności finansów publicznych ${ }^{24}$.

Nałożenie przez władzę państwową obowiązku samoopodatkowania niewypłacalnej jednostki samorządowej stanowi urzeczywistnienie założenia, według którego to właśnie mieszkańcy powinni być obarczeni spłatą zadłużenia ich wspólnot samorządowych. W zarysie koncepcyjnym „nakaz działania” może być postrzegany przez władzę lokalną jako bodziec do dokonywania bardziej efektywnej alokacji dóbr i usług, albowiem jednostka samorządowa zdaje sobie sprawę, iż to ona, a nie strona trzecia (państwo lub wierzyciel), będzie ponosić rzeczywiste skutki nadmiernej konsumpcji spożytkowanych zasobów i będzie za nią w finansowy sposób odpowiedzialna ${ }^{25}$. Co w konsekwencji może doprowadzić do tego, że taka j.s.t. ograniczy się z ich wcześniejszym, nieefektywnym wydatkowaniem.

Podźwignięcie j.s.t. ze stanu zapaści finansowej może niekiedy przybrać także bardzo radykalną postać poprzez jej zniesienie. Likwidacja jednostki samorządowej w celu jej podziału pomiędzy ościenne jednostki lub połączenie z inną jednostką stanowi rygorystyczną formę reakcji państwa na niewypłacalność, w razie zajścia której problemem wykonania wymagalnych zobowiązań likwidowanej jednostki zostaje obarczone państwo lub sąsiednie j.s.t. ${ }^{26}$

\subsection{Charakterystyka i ocena metody zaradczej znajdującej zastosowanie w Polsce}

Jak już wspomniano, polskie prawo nie dopuszcza sytuacji, w której jednostka samorządu terytorialnego mogłaby zostać postawiona w stan bankructwa na skutek nadmiernej eskalacji jej zadłużenia. Czy należy zatem

24 Tamże, s. 140-143; M. Bitner, Postępowanie naprawcze $w$ jednostkach samorzqdu terytorialnego - uwagi na tle rozwiqzań $w$ wybranych krajach OECD, „Finanse Komunalne” 2013, nr 4, s. 18-20; W. Gonet, Naprawa finansów samorzq̨du terytorialnego w wybranych krajach, „Finanse Komunalne” 2014, nr 4, s. 77-78

26 Por. W. Gonet, Program naprawczy jednostek samorzqdu terytorialnego..., s. 17. 
uznać, że władza publiczna nie bierze pod uwagę takiej ewentualności? Praktyka życia gospodarczego wskazuje jednak, iż sytuacje te nie są wcale czymś incydentalnym, dowodząc zarazem wagi tego zjawiska ${ }^{27}$. $\mathrm{Z}$ tego też względu władza publiczna tym bardziej nie powinna pozwolić sobie na ignorowanie problemu, którego niekontrolowany przebieg mógłby przecież zachwiać stabilnością finansów całego sektora publicznego. Dlatego też pomimo braku normatywnych rozwiązań w zakresie postępowania upadłościowego j.s.t. do polskiego porządku prawnego wprowadzono jedną z alternatywnych postaci reakcji państwa na brak wypłacalności w obrębie jednostek samorządu terytorialnego. W drodze postanowień ustawy o finansach publicznych z $2009 \mathrm{rr}^{28}$ uregulowano możliwość udzielenia pożyczki z budżetu państwa tym jednostkom samorządowym, które popadły w poważniejsze trudności finansowe. Mechanizm finansowego wsparcia takich jednostek ze strony państwa powszechnie określa się mianem „postępowania naprawczego”, gdyż nadrzędnym celem, jaki mu przyświeca, jest sanacja gospodarki finansowej j.s.t. zagrożonych bądź dotkniętych brakiem płynności ${ }^{29}$. Osiągnięcie zaś tego skutku ma nastąpić poprzez zarówno odpowiednie motywowanie (przez tworzenie i późniejszą realizację programu naprawczego), jak i wspieranie finansowe (przez wyasygnowanie określonej transzy środków z budżetu państwa) tych j.s.t., które znalazły się wprawdzie w sytuacji kryzysowej, ale jednocześnie podejmują starania zmierzające ku polepszeniu takiego stanu rzeczy ${ }^{30}$.

Postępowanie naprawcze zostało uregulowane w art. 224-225 u.f.p. Jego wdrożenie następuje $\mathrm{w}$ przypadku złej sytuacji finansowej j.s.t., a także niskiej skuteczności (lub jej braku) w wykonywaniu ustawowych

Zob. A. Gniadkowski, Dlaczego bogata Lesznowola nagle wpadła w tarapaty, „Wspólnota” 2013, nr 14, s. 44-45; B. Kalinowska, Bankrut - nie bankrut, „Wspólnota” 2001, nr 7, s. 7; M. Kowalski, Zbankrutowała gmina Brzozie, www.gazeta.pl, (dostęp: 30.09.2014 r.); T. Żółciak, Lista ministra, czyli wykaz bankrutów, „Dziennik Gazeta Prawna” z dn. 20 marca 2013, s. 1.

28 Ustawa z dnia 27 sierpnia 2009 r. o finansach publicznych (tekst jedn. Dz.U. z 2013 r., poz. 885 ze zm., dalej: u.f.p.).

29 M. Bitner, Postępowanie naprawcze w jednostkach samorzqdu terytorialnego..., s. 5.

30 E. Ruśkowski, J.M. Salachna (red.), Ustawa o finansach publicznych. Komentarz praktyczny, Gdańsk 2013, s. 883. 
zadań jednostek samorządowych ${ }^{31}$. Kiedy jednak będzie miała miejsce tego rodzaju sytuacja w j.s.t., ażeby mogła z rzeczonego postępowania skorzystać? Odpowiedź na to pytanie zawiera art. 224 pkt 2 lit. b u.f.p., wedle którego złą sytuację finansową j.s.t. należy oceniać przez pryzmat przekroczenia ustawowych limitów: niezachowania równowagi w sekcji bieżącej budżetu oraz nieprzestrzegania indywidualnego wskaźnika spłat zobowiązań. Zainicjowanie zaś samego postępowania naprawczego następuje wyłącznie z inicjatywy danej jednostki samorządowej. Co wynika z treści przepisu art. 224 ust. 3 u.f.p., znajdując także potwierdzenie w literaturze przedmiotu, w której akcentuje się, że Minister Finansów jako organ reprezentujący Skarb Państwa - nie ma kompetencji do jego wszczęcia w trybie działania z urzędu ${ }^{32}$. Pismo (wniosek) inicjujące procedurę naprawczą należy skierować do Ministra Finansów bądź złożyć w BGK - w razie, gdy został on wyposażony w kompetencję udzielania pożyczek na realizację programów naprawczych. Oczywiście, poza samym wnioskiem, który de facto sprowadza się do oświadczenia woli j.s.t. o wdrożeniu odpowiednich działań, musi on być uzupełniony o stosowne załączniki: program postępowania naprawczego, dokumenty zawierające dane umożliwiające dokonanie bieżącej i prognozowanej oceny sytuacji finansowej tej jednostki oraz propozycje zabezpieczenia spłat pożyczki ${ }^{33}$. Liczba niezbędnych załączników do składanego wniosku jest niezwykle duża - aż 23 ich rodzaje, stąd też już wymóg skompletowania ich wszystkich stanowi dość często barierę nie do pokonania dla wielu j.s.t. Procedura ta okazuje się bowiem niezwykle sformalizowania i zarazem czasochłonna i wymaga od j.s.t. zgromadzenia bardzo wielu szczegółowych informacji o stanie ich gospodarki finansowej ${ }^{34}$. Gdy jednak uda się przez nią przejść, dana j.s.t. może liczyć na otrzymanie określonej ilości środków, udzielonych w ramach zawartej ze Skarbem Państwa umowy pożyczki z budżetu państwa.

\footnotetext{
Tamże, s. 884.

P. Smoleń (red.), Ustawa o finansach publicznych. Komentarz, Warszawa 2014, s. 1100. Tamże.

Zob. § 3 rozporządzenia Ministra Finansów z dnia 23 grudnia 2010 r. w sprawie pożyczek z budżetu państwa udzielanych jednostkom samorządu terytorialnego w ramach postępowań ostrożnościowych lub naprawczych (Dz.U. z 2010 Nr 257, poz. 1730 ze zm.).
} 
Przechodząc do oceny zaprezentowanych powyżej rozwiązań, nie sposób najpierw nie odnieść się do pewnych mankamentów, jakie tu się uwidaczniają. Otóż już na pierwszy rzut oka widać, że nie stanowią one kompleksowego rozwiązania kwestii postępowania naprawczego, a tylko pewien jego etap, który dodatkowo odznacza się dość ubogą osnową normatywną. Można wręcz pokusić się w tym miejscu o stwierdzenie, że tego rodzaju fragmentaryczna regulacja niezwykle przecież ważnej problematyki, jaką jest zapobieżenie negatywnym skutkom niewypłacalności j.s.t., rodzi daleko idący niedosyt ${ }^{35}$. Dlatego jako pierwszy wniosek de lege ferenda należałoby uznać postulat dalszej jej „rozbudowy”, zawierającej, m.in. dookreślenie przesłanek uruchomienia postępowania, kompetencji organów j.s.t. w zakresie wszczęcia i realizacji postępowania, koniecznych elementów doprecyzowujących sam program naprawczy, a także rozszerzenia katalogu ewentualnych uprawnień organów nadzoru o zatwierdzanie programów naprawczych oraz kontrolę ich realizacji ${ }^{36}$. W dalszej kolejności powinno się rozważyć nadanie mu bardziej realnego charakteru, gdyż jak na razie ma on dość iluzoryczny wymiar ${ }^{37}$. Przede wszystkim z powodu niewystarczającej ilości środków budżetowych, które rokrocznie były przeznaczane na ten cel - w kolejnych ustawach budżetowych (2008-2013) Minister Finansów był władny do udzielenia pożyczek j.s.t. w ramach postępowania naprawczego w łącznej kwocie nieprzekraczającej $30 \mathrm{mln}$ (w każdym ze wskazanych lat budżetowych), co przy ewentualnej skali potrzebujących samorządów jest - delikatnie

35 Warto nadmienić, iż choć część postulatów przedstawicieli doktryny została już spełniona za sprawą ubiegłorocznej nowelizacji u.f.p., na mocy której uzupełniono postępowanie naprawcze o brakujący program - zob. art. 240a u.f.p., to wciąż można dostrzec w tej materii pewne luki, które próbuje się uzupełniać w drodze kolejnych nowelizacji. Tytułem przykładu: rzqdowy projekt ustawy o zmianie ustawy o finansach publicznych oraz niektórych innych ustaw z dnia 28 marca 2014 r., przewiduje m.in. dalsze doprecyzowanie programu postępowania naprawczego - Zob. Rzq̨dowy projekt ustawy o zmianie ustawy o finansach publicznych oraz niektórych innych ustaw z dnia 28 marca 2014 r., druk sejmowy nr 2259, s. 3, http://bip.kprm.gov.pl/kpr/bip-radyministrow/projekty-ustaw-przeslan/296,Projekty-ustaw-przeslane-do-Sejmu-RP.html, (dostęp: 30.09.2014 r.).

M. Bitner, Postępowanie naprawcze w jednostkach samorzqdu terytorialnego..., s. 19.

E. Ruśkowski, J.M. Salachna (red.), Ustawa o finansach..., s. 885. 
rzecz ujmując - niedostateczne ${ }^{38}$. Czy wobec zbyt szczupłej puli środków w budżecie na ten cel, które w istocie nie są w stanie zaspokoić rzeczywistej skali potrzeb potencjalnych „bankrutów”, nie należałoby się zastanowić nad zdjęciem całości lub też części finansowego ciężaru realizacji programu naprawczego z budżetu państwa i przeniesienie go na wierzycieli j.s.t. oraz samą jednostkę ${ }^{39}$ ? A zatem uczynienia z niego bardziej realnego narzędzia, które mogłoby zostać wyposażone w dwa niezależne źródła finansowania - środki z budżetu oraz zasoby wierzycieli prywatnych bądź samorządu - aniżeli jedno, które dotychczas, jak wynika z przedstawionego powyżej zestawienia, jest niewydolne. Za odstąpieniem od obecnego rozwiązania opowiada się także M. Wiewióra ${ }^{40}$, pracownik Ministerstwa Finansów, pisząc, że „w warunkach polskich wymaga rozważenia rezygnacja z bezpośredniej pomocy finansowej z budżetu państwa w postaci pożyczek dla jednostek samorządowych na rzecz udzielania przez państwo gwarancji dla kredytu zaciąganego na rynku kapitałowym (...) w ramach postępowania naprawczego”. Zważając na fakt, iż zalążek pewnej idei przemodelowania obowiązującego dotychczas postępowania naprawczego zaczął już rozwijać się u przedstawicieli resortu finansów, można więc z pewną dozą ostrożności spodziewać się $\mathrm{w}$ niedalekim czasie zmian w tym zakresie.

\section{Podsumowanie}

Reasumując rozważania na temat niewypłacalności j.s.t., należy w pierwszej kolejności podkreślić rosnące znaczenie tego zjawiska dla utrzymania stabilności finansów publicznych państwa. Za szczególnie godne rozważenia w tym względzie zdaje się uchodzić dotychczasowe doświadczenie niektórych krajów w przezwyciężaniu tego zjawiska, które może skłaniać do opowiedzenia się za ustanowieniem instytucji upadłości samorządu terytorialnego jako efektywnej metody zaradczej, będącej w stanie zabez-

38 Tamże, s. 886.

39 Por. W. Gonet, Naprawa finansów samorzqdu terytorialnego..., s. 77.

${ }^{40}$ M. Wiewióra, Środki zaradcze państwa wobec niewypłacalności..., s. 46. 
pieczyć wspólnoty lokalne przed widmem niekontrolowanego bankructwa. Na kanwie powyższych uwag z pewną dozą krytycyzmu autor odnosi się do obecnie obowiązującej w Polsce metody (postępowania naprawczego), która - jak dowodzi praktyka - posiada w istocie dość fikcyjny charakter. Zarówno bowiem ubogość treściowa unormowań prawnych, w których się zawiera, jak i niewystarczająca ilość środków z budżetu państwa asygnowana co roku na ten cel, nie pozwalają uczynić zeń na tyle sprawnego narzędzia, które w wystarczającym stopniu byłoby w stanie wesprzeć niewypłacalne jednostki w przezwyciężeniu dotykającej je finansowej zapaści. Stąd też ewentualne wnioski de lege ferenda wysuwane w tym zakresie powinny zmierzać z jednej strony ku wyeliminowaniu niewątpliwych braków istniejącej regulacji, z drugiej zaś nadaniu jej zdecydowanie bardziej realnych konturów.

\section{Bibliografia:}

Avoiding local government financial crisis: the role of state oversight, Report No 329 Citizens Research Council of Michigan 2000, www.crcmich.org/ PUBLICAT/2000s/2000/rpt329.pdf, (dostęp: 30.09.2014 r.).

Babczuk A., Dług samorzqdowy w Polsce - propozycje de lege ferenda, [w:] L. Patrzałek (red.), Finansowanie jednostek samorzqdu terytorialnego w Polsce, Wydawnictwo Wyższej Szkoły Bankowej, Poznań-Wrocław 2004.

Bitner M., Gmina na rynku kapitałowym. Podstawy zarzqdzanie długiem komunalnym, Agencja Rozwoju Komunalnego, Warszawa 1999.

Bitner M., Postępowanie naprawcze w jednostkach samorzqdu terytorialnego uwagi na tle rozwiqzań $w$ wybranych krajach OECD, „Finanse Komunalne” 2013, nr 4, s. 5-20.

Black J., Słownik ekonomii, Wydawnictwo Naukowe PWN S.A., Warszawa 2008.

Duve T., Drechsler W., Insolvent Local Government: Lesson from Germany, s. 7-9, http://www.nispa.org/files/conferences/2010/papers/201004121221300.Duve_ Drechsler.pdf, (dostęp: 30.09.2014 r.).

Gonet W., Naprawa finansów samorzq̨du terytorialnego w wybranych krajach, „Finanse Komunalne” 2014, nr 4, s. 64-79.

Gonet W., Program naprawczy jednostek samorzqdu terytorialnego w sytuacji utraty zdolności wykonania zobowiqzzań, „Finanse Komunalne” 2008, nr 3, s. $16-25$. 
Gniadkowski A., Dlaczego bogata Lesznowola nagle wpadła w tarapaty, „Wspólnota” 2013, nr 14, s. 44-45.

Groves S.M., An Introduction to Evaluating Financial Condition, [w:] J. Matzer, Practical Financial Management. New Techniques for Local Government, ICMA (International City Management Association), Washington 1984.

Gruszka B., Ryzyko płynności finansowej, [w:] L. Jaworski (red.), Współczesny bank, Poltext, Warszawa 2001.

Kalinowska B., Bankrut - nie bankrut, „Wspólnota” 2001, nr 7, s. 7.

Kopańska A., Zewnętrzne źródła finansowania inwestycji jednostek samorzq̨du terytorialnego, Difin, Warszawa 2003.

Kowalski M., Zbankrutowała gmina Brzozie, www.gazeta.pl, (dostęp: 30.09.2014 r.).

Przychodzki M., Sąciński K., Brak zdolności upadłościowej osób prawa publicznego, „Przegląd Prawa Handlowego” 2006, nr 4, s. 27-33.

Ruśkowski E., Salachna J. M. (red.), Ustawa o finansach publicznych. Komentarz praktyczny, Ośrodek Doradztwa i Doskonalenia Kadr, Gdańsk 2013.

Smoleń P. (red.), Ustawa o finansach publicznych. Komentarz, C.H. Beck, Warszawa 2014.

Stolorz-Krzisz E., Niewypłacalność gminy, „Wspólnota”1998, nr 18, s. 11-12.

Swianiewicz S., Finanse samorzqdowe, koncepcje, realizacja, podatki lokalne, Municipium S.A., Warszawa 2011.

Szarek R., Upadłość komunalnych jednostek organizacyjnych, „Wspólnota” 1998, nr 31, s. 24-25.

Wiewióra M., Środki zaradcze państwa wobec niewypłacalności jednostki samorzq̨du terytorialnego, „Samorząd Terytorialny” 2009, nr 12, s. 34-46.

Wronkowska S., Ziembiński Z., Zarys teorii prawa, Ars boni et aequi, Poznań 1997.

Zieliński M., Wykładnia prawa. Zasady, reguły, wskazówki, LexisNexis, Warszawa 2010.

Zimmermann J., Prawo administracyjne, Zakamycze, Kraków 2005.

Żółciak T., Lista ministra, czyli wykaz bankrutów, „Dziennik Gazeta Prawna” z dn. 20 marca 2013, s. 1. 